\title{
FAKTOR- FAKTOR YANG MEMPENGARUHI PROFITABILITAS PERBANKAN \\ (Studi Kasus pada Bank Umum yang Terdaftar di Bursa Efek Indonesia Periode 2015 -2017)
}

\author{
Nyimas Vila Dewi \\ Mahasiswa Magister Manajemen Pascasarjana Universitas Islam Malang \\ Email : Nyimasviladewi00@gmail.com
}

\begin{abstract}
Abstrak
Penelitian ini bertujuan untuk mengetahui faktor- faktor yang mempengaruhi profitabilitas dengan CAR, NIM, LDR dan BOPO sebagai variabel endogen, ROE sebagai variabel eksogen dan NPL sebagai variabel intervening. Alat analisis pada penelitjian ini adalah software AMOS 24. Sampel dari penelitian ini adalah bank umum yang terdaftar di Bursa Efek Indonesia dan mempublikasikan laporan keuangannya periode 2015- 2017.

34 bank umum yang menjadi populasi penelitian ini, hasil penelitian menunjukkan bahwa CAR, BOPO berpengaruh signifikan terhadap ROE dan NIM, LDR tidak berpengaruh signifikan terhadap ROE. CAR, LDR BOPO berpengaruh signifikan terhadap ROE dengan NPL sebagai variabel intervening dan NIM tidak berpengaruh signifikan terhadap ROE dengan NPL sebagai variabel intervening. Semakin tinggi nilai CAR dan NIM maka akan semakin tinggi nilai profitabilitas (ROE) dan sebaliknya semakin rendah nilai LDR dan BOPO maka semakin rendah profitabilitas (ROE).

Kata kunci: CAR (Capital Adequacy Ratio), NPL (Non Performing Loan), NIM (Net Interest Margin), LDR (Loan to Deposit Ratio) BOPO (Beban Operasional terhadap Pendapatan Operasional) dan ROE (Return On Equity).
\end{abstract}

\footnotetext{
Abstract

The purpose of this research is to examine the factors take effect on Bank Profitability by CAR, NIM, LDR and BOPO as endogenous variable, ROE as exogenous variable and NPL as intervening variable. The analytical of this resereach is software AMOS 24. The samples are public bank at The Indonesian Stock Exchange that have complete financial report and have been published in 2015-2017. Public bank at The Indonesian Stock Exchange that is still exist during observation period in 2015-2017.

Population that is used in this research is 34 banks in Indonesian Stock Exchange in 2015-2017. The result of research showed that endogenous variable CAR and BOPO has significant effect partially on ROE, NIM and LDR has not significant effect partially on ROE. CAR, NIM and BOPO has significant effect partially on ROE with NPL as intervening variable and LDR has not significant effect partially on ROE with NPL as intervening variable. The firm that has higher score of CAR and NIM will gain higher profitability (ROE) whereas if it has higher score of $L D R$ and BOPO, the profitability (ROE) will be lower.

Key words: CAR (Capital Adequacy Ratio), NPL (Non Performing Loan), NIM (Net Interest Margin), LDR (Loan to Deposit Ratio) BOPO and ROE (Return On Equity).
} 


\section{PENDAHULUAN}

Pengertian bank menurut Undang- Undang RI Nomor 10 Tahun 1988 tanggal 10 November 1998 adalah: "Badan usaha yang menghimpun dana dari masyarakat dalam bentuk simpanan dan menyalurkannya kepada masyarakt dalam bentuk kredit dan / atau bentuk - bentuk lainnya dalam rangka meningkatkan taraf hidup rakyat banyak" (Kasmir, 2012: 13). Strategi bank agar masyarakat bersedia menanamkan dananya adalah dengan memberikan balas jasa yang menarik dan menguntungkan seperti simpanan giro dan tabungan serta bunga bank yang mampu memberikan keuntungan lebih bagi nasabahnya. Disamping itu, kredit yang diberikan bank dapat membantu mengembangkan usaha masyarakat sehingga mendorong pertumbuhan ekonomi, dengan demikian peran bank sangat diperlukan dalam rangka meningkatkan aktivitas perdagangan dan dunia usaha melalui terciptanya iklim perbankan yang sehat (Hasibuan, 2005 :172).

Profitabilitas merupakan suatu kemampuan yang dimiliki oleh perusahaan dalam menghasilkan keuntungan atau laba pada periode waktu tertentu. Dalam mengukur profitabilitas perusahaan menggunakan rasio (ROE) Return on Equity untuk mengukur laba bersih sesudah pajak dengan modal sendiri. Rasio ini menunjukkan efisiensi penggunaan modal sendiri, semakin tinggi rasio ini semakin baik, artinya posisi pemilik perusahaan semakin kuat, demikian pula sebaliknya (Kasmir (2013:204). Beberapa faktor yang dapat mempengaruhi profitabilitas perbankan yaitu: kredit macet ( Non Performing Loan ), Inflasi, NIM (Net Interest Margin), LDR (Loan Deposit Ratio), suku bunga BI (BI rate), DPK (Dana Pihak Ketiga), BOPO (Beban Operasional terhadap Pendapatan Operasional), CAR (Capital Adequency Ratio), kurs (nilai tukar mata uang), Dana pihak kedua (DP-2), GWM (Giro Wajib Minimum), likuiditas dan lain- lain. Dalam analisis CAMEL untuk menilai kinerja perbankan menggunakan 5 aspek penting yaitu: Capital, Asset, Management, Earning, Liquidity. Aspek Capital meliputi CAR (Capital Adequacy Ratio), aspek Asset meliputi NPL (Non Performing Loan), aspek Earning meliputi NIM (Net Interest Margin Ratio) dan BOPO (Biaya Operasional dan Pendapatan Operasional) dan aspek likuiditas meliputi LDR (Loan To Deposit Rasio). Dengan alasan ini, peneliti fokus pada 5 rasio yang mempengaruhi profitabilitas perbankan yaitu: CAR (Capital Adequacy Ratio), NPL (Non Performing Loan), NIM (Net Interest Margin Ratio), BOPO (Biaya Operasional dan Pendapatan Operasional) dan LDR (Loan To Deposit Rasio).

NPL atau Kredit bermasalah adalah kegagalan pihak debitur memenuhi kewajibannya untuk membayar angsuran (cicilan) pokok kredit beserta bunga bunga yang telah disepakati kedua belah pihak dalam perjanjian kredit Dendawijaya, (2009). NPL mencerminkan risiko kredit, semakin tinggi NPL mengakibatkan semakin tinggi risiko kredit bermasalah yang berpotensi akan menurunkan profitabilitas yang diperoleh perbankan. Sehingga pada penelitian ini peneliti memilih NPL (Non Performing Loan) sebagai variabel Intervening.

Sesuai dengan latar belakang dan rumusan masalah yang ada, maka tujuan penelitian ini adalah sebagai berikut: 
1. Untuk menguji dan menganalisis pengaruh CAR (Capital Adequacy Ratio) terhadap ROE (Return On Equity) pada Bank Umum yang terdaftar di Bursa Efek Indonesia.

2. Untuk menguji dan menganalisis pengaruh NIM (Net Interest Margin) terhadap ROE (Return On Equity) pada Bank Umum yang terdaftar di Bursa Efek Indonesia.

3. Untuk menguji dan menganalisis pengaruh LDR (Loan To Deposit Rasio) terhadap ROE (Return On Equity) pada Bank Umum yang terdaftar di Bursa Efek Indonesia .

4. Untuk menguji dan menganalisis pengaruh BOPO (Biaya Operasional dan Pendapatan Operasional) terhadap ROE (Return On Equity) pada Bank Umum yang terdaftar di Bursa Efek Indonesia.

5. Untuk menguji dan menganalisis pengaruh CAR (Capital Adequacy Ratio) terhadap ROE (Return On Equity) dengan NPL sebagai variabel intervening.

6. Untuk menguji dan menganalisis pengaruh NIM (Net Interest Margin) terhadap ROE (Return On Equity) dengan NPL (Non Performing Loan) sebagai variabel intervening.

7. Untuk menguji dan menganalisis pengaruh LDR (Loan To Deposit Rasio) terhadap ROE (Return On Equity) dengan NPL (Non Performing Loan) sebagai variabel intervening.

8. Untuk menguji dan menganalisis pengaruh BOPO (Biaya Operasional dan Pendapatan Operasional) terhadap ROE (Return On Equity) dengan NPL (Non Performing Loan) sebagai variabel intervening.

\section{KAJIAN TEORI}

\section{Profitabilitas Bank}

Profitabilitas merupakan suatu kemampuan yang dimiliki oleh perusahaan dalam menghasilkan keuntungan atau laba pada periode waktu tertentu. ROE (Return on Equity) merupakan rasio untuk mengukur laba bersih sesudah pajak dengan modal sendiri. Rasio ini menunjukkan efisiensi penggunaan modal sendiri, semakin tinggi rasio ini semakin baik, artinya posisi pemilik perusahaan semakin kuat, demikian pula sebaliknya (Kasmir, 2012:204).

\section{Non Performing Loan (NPL) dan Pengaruhnya Terhadap Return On Equity (ROE)}

Kredit bermasalah atau kredit macet adalah kredit yang didalamnya terdapat hambatan yang disebabkan oleh 2 unsur yakni dari pihak perbankan dalam menganalisis maupun dari pihak nasabah yang dengan sengaja atau tidak sengaja dalam kewajibannya tidak melakukan pembayaran, (Kasmir, 2013:155). Kredit bermasalah atau kredit macet disebabkan oleh Pihak perbankan (kreditur)kurang teliti dalam mengecek kebenaran dan keaslian dokumen maupun salah dalam melakukan perhitungan dengan rasio-rasio yang ada dan dari pihak debitur adanya unsur kesengajaan. Artinya debitur sengaja tidak mau membayar kewajibannya kepada bank sehingga kredit yang diberikan dengan sendirinya macet. 
Semakin tinggi NPL maka akan semakin tinggi risiko kredit bermasalah dan berpotensi akan menurunkan keuntungan yang diperoleh perbankan dan sebaliknya semakin rendah nilai NPL maka tingkat kredit bermasalahakan semakin baik. Hal ini dapat dilihat pada lampiran 2.2 (Data Empiris Hubungan Antara CAR, NPL, NIM LDR dan BOPO Terhadap ROE), semakin tinggi tingkat rasio NPL akan berdampak pada penurunan tingkat rasio ROE dan sebaliknya semakin rendah rasio NPL maka akan meningkatkan rasio ROE pada perbankan.

\section{Capital Adequacy Ratio (CAR) dan Pengaruhnya Terhadap Return On Equity (ROE)}

Menurut Hasibuan (2005:58) CAR adalah kebutuhan modal minimum bank dihitung berdasarkan Aktiva Tertimbang Menurut Resiko (ATMR) . Rasio kebutuhan modal bank dihitung dengan cara membandingkan modal sendiri. ATMR (Aktiva Tertimbang Menurut Resiko) merupakan penjumlahan anktiva neraca dan aktiva administrasi.

Berdasarkan lampiran 2.2 (Data Empiris Hubungan Antara CAR, NPL, NIM LDR dan BOPO Terhadap ROE), semakin tinggi nilai CAR maka akan semakin baik kemampuan bank untuk menanggung risiko dari setiap kredit/aktiva produktif yang berisiko yang artinya akan mampu meningkatkan nilai ROE dan sebaliknya semakin rendah nilai CAR maka semakin rendah pula nilai ROE perbankan.

\section{Net Interest Margin ( NIM ) dan Pengaruhnya Terhadap Return On Equity (ROE)}

Menurut Frianto Pandia (2012:71) Net Interest Margin (NIM) adalah Rasio yang digunakan untuk mengukur kemampuan manajemen bank dalam mengelola aktiva produktifnya untuk menghasilkan pendapatan bunga bersih.

Berdasarkan lampiran 2.2 (Data Empiris Hubungan Antara CAR, NPL, NIM LDR dan BOPO Terhadap ROE), semakin besar nilai NIM yang dicapai oleh suatu bank maka akan meningkatkan pendapatan bunga atas aktiva produktif yang dikelola oleh bank yang bersangkutan sehingga ROE juga akan meningkat dan sebaliknya semakin rendah nilai NIM maka semakin rendah pula nilai ROE perbankan.

\section{Loan to Deposit Ratio (LDR) dan Pengaruhnya Terhadap Return On Equity (ROE)}

Loan to Deposit Ratio (LDR) merupakan rasio untuk mengukur komposisijumlah kredit yang diberikan dibandingkan dengan jumlah dana masyarakat dan modal sendiri yang digunakan (Kasmir, 2014: 319). Rasio LDR dihitung dengan membandingkan kredit dengan dana pihak ketiga dimana kredit yang digunakan merupakan total kredit yang diberikan kepada pihak ketiga, dan tidak termasuk kredit yang diberikan kepada pihak lain. 
Berdasarkan lampiran 2.2 (Data Empiris Hubungan Antara CAR, NPL, NIM LDR dan BOPO Terhadap ROE), semakin kecil nilai LDR maka akan semakin besar laba yang diperoleh pihak bank yang artinya nilai ROE akan meningkat dan sebaliknya semakin tinggi nilai LDR maka akan menurunkan nilai ROE perbankan.

\section{Biaya Operasional terhadap Pendapatan Operasional (BOPO) dan Pengaruhnya Terhadap Return On Equity (ROE)}

Menurut Frianto Pandia (2012:72) mengatakan BOPO digunakan untuk mengukur kemampuan manajemen bank dalam mengendalikan biaya operasional terhadap pendapatan operasional.

Semakin kecil rasio BOPO akan lebih baik, karena bank yang bersangkutan dapat menutup beban operasional dengan pendapatan operasionalnya yang artinya artinya nilai ROE akan meningkat dan sebaliknya semakin tinggi nilai BOPO maka akan menurunkan nilai $\mathrm{ROE}$ perbankan.

\section{METODE PENELITIAN}

Jenis penelitian ini adalah explanatory research (eksplanatori) yaitu penelitian yang digunakan untuk menjelaskan hubungan kausal antara variabel-variabel melalui pengujian hipotesa yang dirumuskan atau sering kali disebut sebagai penelitian penjelas, Singarimbun dan Effendi (2006:4). Penelitian disusun berdasarkan 34 laporan keuangan bank umum yang terdaftar di Bursa Efek Indonesia periode 2015-2017.

\section{Populasi dan Sampel}

Menurut Wathen (2012), Populasi merupakan keseluruhan individu atau objek tertentu atau ukuran yang diperoleh dari semua individu atau objek tertentu. Pada tanggal 29 Desember 2018 melalui website www.idx.co.id, sebanyak 622 perusahaan yang terdaftar di Bursa Efek Indonesia diantaranya adalah 43 industri bank umum yang terdaftar di Bursa Efek Indonesia periode 2015 - 2017.

Pengambilan sampel penelitian dilakukan dengan metode purposive sampling, yaitu metode pengambilan sampel berdasarkan kriteria-kriteria dan pertimbangan tertentu Sugiyono (2012).

\section{Operasionalisasi Variabel}

\section{Capital Adequacy Ratio (CAR)}

Menurut Hasibuan (2005:58) CAR (Capital Adequacy Ratio) adalah kebutuhan modal minimum bank dihitung berdasarkan Aktiva Tertimbang Menurut Resiko (ATMR) . Rasio kebutuhan modal bank dihitung dengan cara membandingkan modal sendiri dengan ATMR dengan rumus:

$$
\mathrm{CAR}=\frac{\text { Modal sendiri (Modal sendiri }+ \text { Modal pelengkap) }}{\text { ATMR (Neraca Aktiva }+ \text { neraca Administrasi) }} \times 100 \%
$$

ATMR (Aktiva Tertimbang Menurut Resiko) merupakan penjumlahan anktiva neraca dan aktiva administrasi. Semakin tinggi nilai CAR (Capital 
Adequacy Ratio) maka akan semakin baik kemampuan bank untuk menanggung risiko dari setiap kredit/aktiva produktif yang berisiko.

\section{Net Interest Margin ( NIM )}

Menurut Frianto Pandia (2012:71) NIM (Net Interest Margin) adalah Rasio yang digunakan untuk mengukur kemampuan manajemen bank dalam mengelola aktiva produktifnya untuk menghasilkan pendapatan bunga bersih. Sesuai dengan Surat Edaran No.6/23/DPNP tanggal 31 Mei 2004 besaran rasio NIM dapat dihitung dengan rumus :

$$
\mathrm{NIM}=\frac{\text { Pendapatan bunga bersih }}{\text { rata-rata aktiva produktif }} \times 100 \%
$$

Semakin besar nilai NIM (Net Interest Margin) yang dicapai oleh suatu bank maka akan meningkatkan pendapatan bunga atas aktiva produktif yang dikelola oleh bank yang bersangkutan, sehingga laba bank juga akan meningkat.

\section{Loan to Deposit Ratio (LDR)}

Loan to Deposit Ratio (LDR) merupakan rasio untuk mengukur komposisijumlah kredit yang diberikan dibandingkan dengan jumlah dana masyarakat dan modal sendiri yang digunakan (Kasmir, 2014: 319). Rasio LDR dihitung dengan membandingkan kredit dengan dana pihak ketiga dimana kredit yang digunakan merupakan total kredit yang diberikan kepada pihak ketiga, dan tidak termasuk kredit yang diberikan kepada pihak lain.

$$
\operatorname{LDR}=\frac{\text { Jumlah kredit pihak ketiga }}{\text { Total dana pihak ketiga }} \times 100 \%
$$

\section{Biaya Operasional terhadap Pendapatan Operasional (BOPO)}

Menurut Frianto Pandia (2012:72) mengatakan BOPO digunakan untuk mengukur kemampuan manajemen bank dalam mengendalikan biaya operasional terhadap pendapatan operasional. Rasio ini dapat dirumuskan sebagai berikut:

\section{Profitabilitas Bank}

$$
\mathrm{BOPO}=\frac{\text { Total beban operasional }}{\text { total pendapatan operasional }} \times 100 \%
$$

Profitabilitas merupakan suatu kemampuan yang dimiliki oleh perusahaan dalam menghasilkan keuntungan atau laba pada periode waktu tertentu. ROE (Return on Equity) merupakan rasio untuk mengukur laba bersih sesudah pajak dengan modal sendiri. Rasio ini menunjukkan efisiensi penggunaan modal sendiri, semakin tinggi rasio ini semakin baik, artinya posisi pemilik perusahaan semakin kuat, demikian pula sebaliknya (Kasmir, 2012:204). Rasio ROE (Return on Equity) dapat dihitung melalui rumus:

$$
\mathrm{ROE}=\frac{\text { Laba bersih setelah pajak }}{\text { Ekuitas }} \times 100 \%
$$




\section{Non Performing Loan (NPL)}

Kredit bermasalah atau kredit macet adalah kredit yang didalamnya terdapat hambatan yang disebabkan oleh 2 unsur yakni dari pihak perbankan dalam menganalisis maupun dari pihak nasabah yang dengan sengaja atau tidak sengaja dalam kewajibannya tidak melakukan pembayaran, (Kasmir, 2013:155). Kredit bermasalah atau kredit macet disebabkan oleh Pihak perbankan (kreditur) kurang teliti dalam mengecek kebenaran dan keaslian dokumen maupun salah dalam melakukan perhitungan dengan rasio-rasio yang ada dan dari pihak debitur adanya unsur kesengajaan. Artinya debitur sengaja tidak mau membayar kewajibannya kepada bank sehingga kredit yang diberikan dengan sendirinya macet.

\section{Metode Analisis Data}

$$
\text { NPL }=\frac{\text { Pembiayaan tidak lancar }}{\text { total pembiayaan }} \times 100 \%
$$

1. Penelitian pustaka, dilakukan dengan cara mengumpulkan buku literatur yang ada hubungannya dengan penulisan tesis, dengan tujuan agar mendapatkan landasan teori dan teknik analisis dalam memecahkan masalah.

2. Pengumpulan dan pencatatan data laporan tahunan pada masingmasing bank umum yang terdaftar di Bursa Efek Indonesia (BEI) yang menjadi sampel, untuk mengetahui rasio-rasio keuangannya selama periode 2015 - 2017.

3. Data dalam penelitian ini diperoleh dari media internet dengan cara mengambil melalui situs bank yang menjadi objek penelitianan.

\section{HASIL ANALISIS DATA}

\section{Analisis Deskriptif Statistik}

\section{Tabel 4.2 Deskriptif Statistik}

\begin{tabular}{|l|c|c|c|c|c|}
\hline & $\mathrm{N}$ & $\begin{array}{c}\text { Minimu } \\
\mathrm{m}\end{array}$ & $\begin{array}{c}\text { Maximu } \\
\mathrm{m}\end{array}$ & Mean & Std. Deviation \\
\hline CAR & 102 & 2.16 & 35.17 & $\begin{array}{c}19.475 \\
6\end{array}$ & 6.36598 \\
\hline NIM & 102 & 1.93 & 9.30 & 5.0244 & 1.70232 \\
\hline LDR & 102 & 42.02 & 112.54 & $\begin{array}{c}83.967 \\
6\end{array}$ & 14.16613 \\
\hline BOPO & 102 & 57.04 & 133.06 & $\begin{array}{c}89.063 \\
0\end{array}$ & 13.52220 \\
\hline NPL & 102 & .03 & 6.07 & 2.3789 & 1.40852 \\
\hline ROE & 102 & -18.09 & 34.89 & 7.1211 & 10.41950 \\
\hline
\end{tabular}

Sumber : Hasil output SPSS, data sudah diolah 2019 


\section{Uji Normalitas}

Tabel 4.2

Assessment of normality

\begin{tabular}{|l|rrrrrr|}
\hline Variable & $\min$ & $\max$ & skew & c.r. & kurtosis & c.r. \\
\hline BOPO & 57.600 & 128.680 & .584 & 2.384 & 1.001 & 2.043 \\
CAR & 2.160 & 35.170 & .019 & .079 & 1.087 & 2.219 \\
LDR & 42.020 & 112.540 & -.580 & -2.368 & .812 & 1.658 \\
NIM & 1.930 & 9.300 & .260 & 1.062 & -.263 & -.537 \\
NPL & .050 & 6.070 & .649 & 2.469 & -.049 & -.100 \\
ROE & -18.090 & 34.890 & -.630 & -2.571 & .815 & 1.664 \\
Multivariate & & & & & 2.497 & 1.504 \\
\hline
\end{tabular}

Berdasarkan hasil perhitungan uji normalitas pada tabel 4.2 menunjukkan bahwa tidak ada nilai critical ratio (c.r) yang berada diatas 2,58 dan dibawah -2,58. Sehingga dapat disimpulkan bahwa semua variabel pada penelitian ini berdistribusi normal.

\section{Uji Outlier}

Berdasarkan tabel hasil analisis uji outlier yang disajikan dalam lampiran 7 terlihat nilai tertinggi terletak pada observasi nomer 98 sebesar 27,247 dengan nilai $p 1$ sebesar 0.00 dan $p 2$ sebesar 0.013 . Nilai $p$ dibawah 0.05 menandakan bahwa pada observasi nomer 98 terdapat data yang cukup besar, maka pada penelitian ini observasi nomer 98 dilakukan outlier sehingga dan uji normalitas dapat terpenuhi seperti yang sajikan pada tabel 4.2

\section{Uji Multikolonieritas}

Uji Multikolonieritas merupakan uji untuk menunjukkan terjadi atau tidaknya hubungan antar variabel bebas.

\section{Correlations}

\begin{tabular}{|lll|c|}
\hline & & & Estimate \\
\hline NIM & $<->$ & CAR & .228 \\
NIM & $<->$ & LDR & .230 \\
LDR & $<-->$ & BOPO & -.138 \\
NIM & $<-->$ & BOPO & -.615 \\
CAR & $<-->$ & BOPO & -.144 \\
LDR & $<->$ & CAR & -.088 \\
\hline
\end{tabular}

Sumber: Amos 24, data diolah 2019

Berdasarkan koefisien korelasi pada tabel diatas menunjukkan bahwa masing- masing nilai korelasi berada pada angka -1 sampai dengan +1 dengan demikian dapat disimpulkan bahwa pada penelitian ini tidak terjadi multikolonieritas antar variabel 


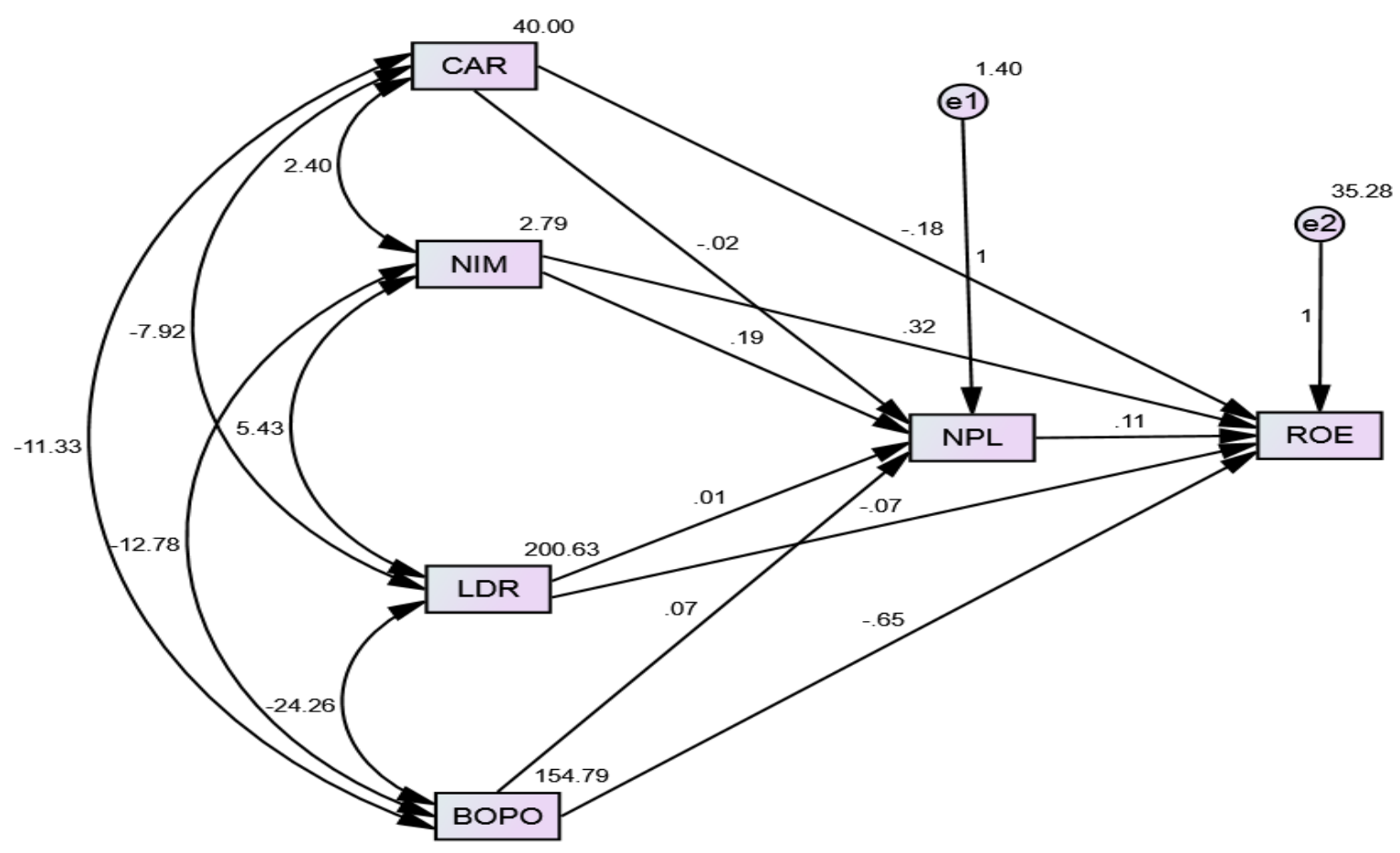

\section{PEMBAHASAN}

\section{Pengaruh Langsung}

Regression Weights

\begin{tabular}{|lll|rrrrl|}
\hline & & & Estimate & S.E. & C.R. & P & Label \\
\hline NPL & $<---$ & NIM & .191 & .094 & 2.031 & .042 & par_1 \\
NPL & $<---$ & LDR & .007 & .009 & .847 & .397 & par_2 \\
NPL & $<---$ & CAR & -.017 & .020 & -.893 & .372 & par_3 \\
NPL & $<---$ & BOPO & .069 & .012 & 5.715 & $* * *$ & par_4 \\
ROE & $<---$ & NPL & .108 & .054 & 1.214 & .038 & par_5 \\
\hline
\end{tabular}




\begin{tabular}{|lll|rrrrr|}
\hline & & & Estimate & S.E. & C.R. & P & Label \\
\hline ROE & $<--$ & BOPO & -.654 & .070 & -9.322 & ${ }^{* * *}$ & par_6 \\
ROE & $<--$ & LDR & -.074 & .044 & -1.689 & .091 & par_7 \\
ROE & $<---$ & NIM & .316 & .481 & .656 & .512 & par_8 \\
ROE & $<---$ & CAR & -.183 & .098 & -1.861 & ${ }^{* * *}$ & par_9 \\
\hline
\end{tabular}

\section{Pengaruh CAR (Capital Adequacy Ratio) terhadap ROE(Return On Equity)}

Berdasarkan output hasil pengolahan data pada tabel regression weight yang disajikan dalam lampiran 7 diperoleh nilai koefisien jalur ( $\beta 1$ ) sebesar $-0,183$ dan $P$ (probability) ditulis dengan lambang tiga bintang $\left.{ }^{* * *}\right)$ yang artinya nilai signifikan lebih kecil dari 0,05 atau $P<0,05$. Hal ini menunjukkan bahwa $\mathrm{H}_{0}$ ditolak. Semakin besar nilai CAR (Capital Adequacy Ratio) maka ROE (Rerurn On Equity) akan semakin tinggi, yang artinya semakin besar modal yang dimiliki suatu bank maka semakin banyak dana yang disediakan untuk keperluan pengembangan usaha serta semakin besar kemampuan bank untuk mengantisipasi adanya risiko kerugian.

Hal ini menunjukkan kemampuan permodalan bank dalam menjaga kemungkinan timbulnya risiko kerugian kegiatan usahanya berpengaruh terhadap tingkat pendapatan yang dihasilkan oleh bank tersebut. Peningkatan modal bank akan memicu tingginya tingkat kesehatan bank pada rasio permodalan CAR (Capital Adequancy Ratio) sehingga semakin kuat kemampuan bank dalam menanggung risiko kerugian dari setiap kredit atau aktiva yang berisiko, sehingga dapat disimpulkan bahwa CAR (Capital Adequancy Ratio) berpengaruh sangat signifikan terhadap ROE (Return On Equity) pada bank umum yang terdaftar di Bursa Efek Indonesia.

\section{Pengaruh NIM (Net Interest Margin) terhadap ROE (Return On Equity)}

Berdasarkan output hasil pengolahan data pada tabel regression weight yang disajikan dalam lampiran 7 diperoleh nilai koefisien jalur ( $\beta 2$ ) sebesar 0,316 dan $P$ (probability) sebesar 0,358 . Dengan taraf signifikansi sebesar 0,05 maka dapat diketahui bahwa nilai $\mathrm{P}$ (probability) 0,512 > 0,05 yang artinya $\mathrm{H}_{0}$ diterima.

NIM (Net Interest Margin) menunjukkan seberapa besar bunga bersih yang diperoleh bank karena bunga bersih yang diperoleh merupakan hasil dari kegiatan utama bank yaitu sebagai pihak penyalur dana kepada pihak yang membutuhkan. Namun salah satu faktor yang mampu menghambat pertumbuhan pendapatan bunga bersih yaitu besarnya beban bunga tabungan dan bunga deposito nasabah Sehingga mengakibatkan menurunnya pendapatan bunga bersih dan berdampak pada berkurangnya laba perbankan atau ROE (Return On Equity). Sehingga dapat disimpulkan bahwa NIM (Net Interest Margin) tidak berpengaruh signifikan terhadap ROE (Return On Equity) pada bank umum yang terdaftar di Bursa Efek Indonesia. 


\section{Pengaruh LDR (Loan to Deposit Ratio) terhadap ROE (Return On Equity)}

Berdasarkan output hasil pengolahan data pada tabel regression weight yang disajikan dalam lampiran 7 diperoleh nilai koefisien jalur (B3) sebesar -0,074 dan P (probability) sebesar 0,091. Dengan taraf signifikansi sebesar 0,05 maka dapat diketahui bahwa nilai $\mathrm{P}$ (probability) 0,091 > 0,05 yang artinya $\mathrm{H}_{0}$ diterima.

Rasio ini meningkat karena pihak bank meminjamkan seluruh dananya sehingga perusahaan cenderung tidak likuid dan sebaliknya rasio yang rendah menunjukkan bank yang likuid karena menunjukkan bahwa bank memiliki kelebihan kapasitas dana yang siap untuk dipinjamkan. Namun pemberian kredit kepada nasabah memiliki risiko yang cukup besar yaitu tidak lancarnya pembayaran kredit atau resiko terjadinya kredit macet. Sehingga dapat disimpulkan bahwa bahwa LDR(Loan to Deposit Ratio) tidak berpengaruh signifikan terhadap ROE (Return On Equity) pada bank umum yang terdaftar di Bursa Efek Indonesia.

\section{Pengaruh BOPO (Beban Operasional terhadap Pendapatan Operasional) terhadap ROE (Return On Equity)}

Berdasarkan output hasil pengolahan data pada tabel regression weight yang disajikan dalam lampiran 7 diperoleh nilai koefisien jalur ( $\beta 4)$ sebesar $-0,654$ dan $P$ (probability) ditulis dengan lambang tiga bintang $\left(^{* * *}\right.$ ) yang artinya nilai signifikan lebih kecil dari 0,05 atau $P<0,05$. Hal ini menunjukkan bahwa $\mathrm{H}_{0}$ ditolak. Nilai rata- rata BOPO pada bank umum yang terdaftar di bursa efek Indonesia periode 2015- 2017 yaitu sebesar $89,0630 \%$ dalam standar tingkat kesehatan bank dapat dinyatakan bahwa BOPO berada pada kategori sangat sehat. Apabila rasio BOPO semakin besar maka biaya operasional semakin tinggi dibandingkan dengan operasional yang artinya ROE (Return On Equity) menurun.

Sehingga dapat disimpulkan bahwa BOPO (Beban Operasional terhadap Pendapatan Operasional) berpengaruh sangat signifikan terhadap ROE (Return On Equity) pada bank umum yang terdaftar di Bursa Efek Indonesia.

\section{Pengaruh tidak Langsung}

Direct Effects

\begin{tabular}{|l|lllll|}
\hline & BOPO & CAR & LDR & NIM & NPL \\
\hline NPL & .069 & -.017 & .007 & .191 & .000 \\
ROE & -.654 & -.183 & -.074 & .316 & .108 \\
\hline
\end{tabular}

Standardized Direct Effects

\begin{tabular}{|l|lllll|}
\hline & BOPO & CAR & LDR & NIM & NPL \\
\hline NPL & .620 & -.079 & .075 & .229 & .000 \\
ROE & -.804 & -.114 & -.104 & .052 & .015 \\
\hline
\end{tabular}

Indirect Effects

\begin{tabular}{|l|lllll|}
\hline & BOPO & CAR & LDR & NIM & NPL \\
\hline NPL & .000 & .000 & .000 & .000 & .000 \\
ROE & .007 & -.002 & .001 & .021 & .000 \\
\hline
\end{tabular}


Standardized Indirect Effects

\begin{tabular}{|l|lllll|}
\hline & BOPO & CAR & LDR & NIM & NPL \\
\hline NPL & .000 & .000 & .000 & .000 & .000 \\
ROE & .009 & -.001 & .001 & .003 & .000 \\
\hline
\end{tabular}

Pengaruh CAR (Capital Adequancy Ratio) terhadap ROE (Return On Equity) dengan NPL (Non Performing Loan) sebagai Variabel Intervening.

Berdasarkan output hasil pengolahan data yang disajikan dalam lampiran 7, diketahui nilai pengaruh langsung CAR (Capital Adequacy Ratio) terhadap ROE (Return On Equity) sebesar -0.144. Dan pengaruh tidak langsung CAR (Capital Adequancy Ratio) terhadap ROE (Return On Equity) melalui NPL (Non Performing Loan) sebesar -0,001.

Semakin tinggi CAR (Capital Adequancy Ratio) maka semakin kuat kemampuan bank untuk menanggung risiko dari setiap kredit/ aktiva produktif yang berisiko dan mampu membiayai operasi bank sehingga akan memberikan kontribusi yang cukup besar profitabilitas. Sehingga dapat disimpulkan bahwa secara tidak langsung CAR (Capital Adequacy Ratio) melalui NPL (Non Performing Loan) berpengaruh signifikan terhadap ROE (Return On Equity).

Sehingga dapat disimpulkan bahwa secara tidak langsung CAR (Capital Adequacy Ratio) melalui NPL (Non Performing Loan) berpengaruh signifikan terhadap ROE (Return On Equity).

\section{Pengaruh NIM (Net Interest Margin) terhadap ROE (Return On Equity) dengan NPL (Non Performing Loan) sebagai Variabel Intervening.}

Berdasarkan output hasil pengolahan data yang disajikan dalam lampiran 7, diketahui nilai pengaruh langsung NIM (Net Interest Margin) terhadap ROE (Return On Equity) sebesar 0.052. Dan pengaruh tidak langsung NIM (Net Interest Margin) terhadap ROE (Return On Equity) melalui NPL (Non Performing Loan) sebesar 0,003.

Pendapatan bunga bersih yang tinggi juga memiliki resiko yang tinggi sehingga dapat mempengaruhi tinggi atau rendahnya profitabilitas yang diterima oleh pihak bank. Semakin tinggi NPL (Non Performing Loan) mengakibatkan semakin tinggi tunggakan bunga kredit yang berpotensi menurunkan pendapatan bunga serta menurunkan pendapatan laba perhusahaan atau ROE (Return On Equity). Sehingga dapat disimpulkan bahwa secara tidak langsung NIM (Net Interest Margin) melalui NPL (Non Performing Loan) tidak berpengaruh signifikan terhadap ROE (Return On Equity)

Pengaruh LDR (Loan to Deposit Ratio) terhadap ROE (Return On Equity) dengan NPL (Non Performing Loan) sebagai Variabel Intervening.

Berdasarkan output hasil pengolahan data yang disajikan dalam lampiran 7, diketahui nilai pengaruh langsung LDR (Loan To Deposit Ratio) terhadap ROE (Return On Equity) sebesar -0.104. Dan pengaruh tidak langsung LDR (Loan To Deposit Ratio) terhadap ROE (Return On Equity) melalui NPL (Non Performing Loan) sebesar 0,001. Kegiatan 
penyaluran kredit yang dilakukan oleh bank dapat mengandung risiko yaitu tidak lancarnya pembayaran kredit dan risiko terjadinya kredit bermasalah atau NPL (Non Performing Loan. Timbulnya kredit bermasalah akan berakibat pada kerugian bank karena dana yang disalurkan oleh bank dalam bentuk kredit tidak kembali bahkan pendapatan bunga yang tidak dapat diterima.

Hal ini menyebabkan bank tidak berani meningkatkan penyaluran kreditnya karena akan berdampak pada kemungkinan dana pihak ketiga tidak dapat dicapai secara optimal. Sehingga dapat disimpulkan bahwa secara tidak langsung LDR (Loan to Deposit Ratio) melalui NPL (Non Performing Loan) berpengaruh signifikan terhadap ROE (Return On Equity).

\section{Pengaruh BOPO (Beban Operasional terhadap PendapatanOperasional) terhadap ROE (Return On Equity) dengan NPL (Non Performing Loan) sebagai Variabel Intervening.}

Berdasarkan output hasil pengolahan data yang disajikan dalam lampiran 7, diketahui nilai pengaruh langsung BOPO (Beban Operasional terhadap Pendapatan Operasonal) terhadap ROE (Return On Equity) sebesar -0.803. Dan pengaruh tidak langsung BOPO (Beban Operasional Terhadap Pendapatan Operasonal) terhadap ROE (Return On Equity) melalui NPL (Non Performing Loan) 0,009.

Pendapatan operasional baik dari pinjaman yang diberikan maupun pendapatan bunga yang tinggi akan mampu meningkatkan profitabilitas bank namun memicu tingginya kredit bermasalah atau NPL (Non Performing Loan) sehingga dapat menyebabkan pembengkakan biaya. Peningkatan NPL (Non Performing Loan) akan menyebabkan pembengkakan pada beban akibat dari peningkatan beban pencadangan aktiva produktif ataupun beban lainnya dan berdampak pada kinerja bank. Sehingga dapat disimpulkan bahwa secara tidak langsung BOPO (Beban Operasional terhadap Pendapatan Operasonal) melalui NPL (Non Performing Loan) berpengaruh signifikan terhadap ROE (Return On Equity).

\section{SIMPULAN DAN SARAN}

1. CAR (Capital Adequancy Ratio) berpengaruh sangat signifikan terhadap ROE (Return On Equity) pada bank umum yang terdaftar di Bursa Efek Indonesia.

2. NIM (Net Interest Margin) tidak berpengaruh signifikan terhadap ROE (Return On Equity) pada bank umum yang terdaftar di Bursa Efek Indonesia.

3. LDR(Loan to Deposit Ratio) tidak berpengaruh signifikan terhadap ROE (Return On Equity) pada bank umum yang terdaftar di Bursa Efek Indonesia.

4. BOPO (Beban Operasional terhadap Pendapatan Operasonal) melalui NPL (Non Performing Loan) berpengaruh signifikan terhadap ROE (Return On Equity). 
5. Sehingga dapat disimpulkan bahwa secara tidak langsung CAR (Capital Adequacy Ratio) melalui NPL (Non Performing Loan) berpengaruh signifikan terhadap ROE (Return On Equity).

6. NIM (Net Interest Margin) melalui NPL (Non Performing Loan) tidak berpengaruh signifikan terhadap ROE (Return On Equity)

7. LDR (Loan to Deposit Ratio) melalui NPL (Non Performing Loan) berpengaruh signifikan terhadap ROE (Return On Equity).

8. BOPO (Beban Operasional terhadap Pendapatan Operasonal) melalui NPL (Non Performing Loan) berpengaruh signifikan terhadap ROE (Return On Equity).

\section{DAFTAR PUSTAKA}

Avrita dan Pangestuti. 2016 . Analisa Pengaruh CAR, NPL, LDR, NIM dan BOPO Tehadap Profitabilitas. Journal Of Management. Volume 5. Nomor 2. PP 1-13.

Dewi, Aminar S. 2017. Pengaruh CAR, BOPO, NPL, NIM, dan LDR Terhadap ROA Pada Perusahaan Di Sektor Perbankan Yang Terdaftar Di Bei Periode 2012-2016. Jurnal Pundi. Volume 1. PP 223- 236.

Dewi, Paramitha K, Mulyadi dan Abdurrakhman. 2015. Analisis Pengaruh CAR, NPL, LDR Dan NIM Terhadap Profitabilitas Perbankan. Jurnal Jaffa. Volume 03. Nomor 1. PP 17-30.

Effendi dan Singarimbun. 2006. Metode Penelitian Survai. LP3ES. Jakarta Hasibuan, Malayu S.P. 2005. Dasar- Dasar Perbankan. PT. Bumi Aksara.Jakarta.

Kasmir. 2012. Bank dan Lembaga Keuangan Lainnya. PT. Raja Grafindo Persada. Jakarta.

Kasmir. 2013. Analisis Laporan Keuangan. PT. Raja Grafindo Persada. Jakarta.

Kasmir. 2014. Manajemen Perbankan. PT. Raja Grafindo Persada. Jakarta.

Kurniasih. 2016. Pengaruh Adequancy Ratio, Non Performing Loan, Loan to Deposit Ratio, Efisiensi Operasi, Non Interest Margin Terhadap Return On Assets. Journal Of Accounting. Volume 2. Nomor 2. PP 114.

Kurniawan dan Yamin. 2011. Regresi dan Korelasi Dalam Genggaman Anda. Salemba Empat. Jakarta.

Pandia, Effendi. 2012. Manajemen Dana dan Kesehatan Bank. Rineka Cipta. Jakarta.

Permatasari. 2017. Pengaruh CAR, LDR, BOPO, NPL dan Ukuran Perusahaan Terhadap Profitabilitas Bank UmumSwasta Nasional Devisa dan Busn Non Devisa. E- Proceding Of Management. Volume 4. Nomer 2. PP 1296-1303.

Pinasti, Farhat W. 2017. Pengaruh CAR, BOPO, NPL, NIM Terhadap Profitabilitas Bank Umum. Jurnal Nominal. Volume VII. Nomor. PP 21-45. 
Rachmandinur, A dan Purwanto. 2016. Pengaruh CAR, BOPO, NPL, NIM Terhadap Profitabilitas Bank. Jurnal Manajemen Bisnis Indonesia. Volume 3. Nomor 3. PP 438- 459.

Santoso, Singgih.2018. Konsep dasar dan Aplikasi SEM dengan AMOS 24. Elex Media Komputondo. Jakarta.

Sudarmawanti, E. 2017. Pengaruh CAR, NPL, BOPO, NIM dan LDR Terhadap ROA. Among Makarti. Volume 10. Nomor 18. PP 1-18.

Wathen, Lind Maechal. 2012. Teknik- Teknik Statistika dalam Bisnis dan Ekonomi. Salemba Empat. Jakarta.

Riduwan dan Kuncoro, Engkos Achmad. 2014. Analisis Jalur. Alfabeta. Bandung

Santoso, Singgih. 2016. Menguasai Statistik dengan SPSS 24. Alfabeta. Bandung

Sulaiman, Wahid. 2004. Analisis Regresi Menggunakan SPSS, Contoh Kasus dan Pemecahannya. Yogyakarta

Sulaiman, Wahid. 2016. Menguasai Statistika dengan SPSS 25. Salemba Empat. Jakarta. 